\title{
Assessment of climate change and prospective analysis on shallow lakes. Las Encadenadas del Oeste watershed, Buenos Aires - Argentina
}

\author{
Influencia del cambio climático y análisis prospectivo en lagos poco profundos. \\ Las Encadenadas del Oeste, Buenos Aires - Argentina
}

\author{
Caroline Tengroth ${ }^{1}$ (I) \\ Alejandra Mabel Geraldi ${ }^{*}$
}

\begin{abstract}
The earth's ecosystem is fragile, and sometimes even small changes in the climate can have impacts on the environment and society. Changes in temperature and precipitation can cause numerous feedbacks that effect the ecosystem of the whole Earth. Many studies hold that the temperature will rise in some places, while other areas will experience a cooling in annual mean temperatures. The study area is famous for its many ponds. These ecosystems will be both physically, biologically, and chemically affected by climate change and its feedbacks. Las Encadenadas del Oeste consists of seven shallow lakes (Epecuen, La Paraguaya, Venado, Del Monte, Cochico, Alsina, and Inchauspe) of various depths and sizes is a closed river basin system aligned in an east-west direction. The objectives of this work are to demonstrate the change in shallow lake size over a period of 20 years and to relate these changes to temperature and precipitation over the basin area for the same period. It is also intended to examine future temperature and precipitation scenarios in the study area. Maximum and minimum temperature data and precipitation data was retrieved from a climate station in Carhue. A multiple regression analysis was performed and five models and the shallow lake area were compared. The water levels in the shallow lakes will continue to fluctuate in the future as precipitation and temperature varies. Temperatures will increase quickly in the area; and around a $3{ }^{\circ} \mathrm{C}$ change is expected before 2099. Only small variations in the temperatures have previously caused the lake to change in size. Precipitation patterns show a high variation, but the change is very small. Minimum temperature, which is already the most significant factor according to the statistical analysis, will in the future be an even more important factor if changes occur.
\end{abstract}

Keywords: ponds; climate change; Argentina; models; precipitation; temperature.

\section{Resumen}

La tierra es un ecosistema frágil, donde pequeños cambios en el clima producen impactos en el medio ambiente y en la sociedad. Muchos estudios sostienen que la temperatura aumentará en algunos lugares, mientras que otras áreas experimentarán un descenso en las temperaturas medias anuales. El área de estudio es importante por sus numerosas lagunas. Estos ecosistemas podrían ser afectados física, biológica y químicamente por el cambio climático y sus reacciones. Las Encadenadas del Oeste consta de 7 lagunas poco profundas (Epecuen, La Paraguaya, Venado, Del Monte, Cochico, Alsina e Inchauspe) de diferente profundidad y tamaño y es un sistema de cuencas fluviales cerradas alineadas en dirección este-oeste. Los objetivos de este trabajo son demostrar el cambio en el tamaño de las lagunas durante un período de 20 años y relacionarlo con la temperatura y la precipitación en el área de la cuenca durante el mismo período de tiempo. También, se pretende examinar los escenarios futuros de temperatura y precipitación. Los datos de temperatura máxima y mínima y los datos de precipitación se obtuvieron de una estación

1 University of Gothenburg. Renströmsgatan 641255 Göteborg, Sweden. caroline.tengroth@gu.se

2 Universidad Nacional del Sur - CONICET. Departamento de Geografía y Turismo 12 de Octubre and San Juan, Bahía Blanca, B8000BFW Buenos Aires, Argentina. ageraldi@criba.edu.ar. * Corresponding author 
meteorológica en Carhue. Se realizó un análisis de regresión múltiple y se compararon 5 modelos y con el área de las lagunas. Los niveles de agua en las lagunas continuarán fluctuando en el futuro a medida que varíen las precipitaciones y la temperatura. Las temperaturas aumentarán rápidamente en la zona. Se espera un cambio de alrededor de $3^{\circ} \mathrm{C}$ hasta 2099. Hasta el momento, pequeñas variaciones en las temperaturas han causado cambios en las superficies de los cuerpos de agua. Los patrones de precipitación muestran una gran variación, pero el cambio es muy pequeño. La temperatura mínima, que ya es el factor más significativo según el análisis estadístico, será en el futuro un factor aún más importante si se producen cambios.

Palabras clave: lagunas; cambio climático; Argentina; modelos; precipitación; temperatura.

\section{Introduction}

A climate change poses many risks to humans and to the global ecosystem. Changes likely to occur in the future are higher temperatures and an increased number of temperature extremes. There will also be a change in precipitation, with both increases and decreases in different parts of the world. A change in rainfall will in turn have an effect on run off patterns and sea level rise. Indirectly this will pose changes on water quality, air and food quality, and changes in ecosystems, industry, agriculture and infrastructure (Rosenzweig, et al., 2007); (Yang and Lu, 2014).

The average global temperature on the surface of the earth has risen by $0.74{ }^{\circ} \mathrm{C} \pm 0.18{ }^{\circ} \mathrm{C}$ when estimated from 1906 to 2005, and the warming over the last 50 years is almost the double of that over the last 100 years (Trenberth et al., 2007). Thus, in the period 2003-2012 it was $0.78{ }^{\circ} \mathrm{C}$ (Hartmann et al., 2013) According to IPCC's SRES scenarios for global average surface temperature change, temperature is expected to increase 2 to $4{ }^{\circ} \mathrm{C}$ by the end of the 21st century compared to the levels in the end of the 20th century (Meehl, Stocker, Collins, and Friedlingstein, 2007).

Leemans and Eickhout (2004) stated that if an increase in $2{ }^{\circ} \mathrm{C}$ occurs over a 1,000 year period $\left(+0.02{ }^{\circ} \mathrm{C}\right.$ per decade $)$ most affected ecosystems will have time to adapt. If however, such a change in temperature increase would happen over a 50 year period many ecosystems would rapidly deteriorate. Therefore, the rate of change is important for predictions of total impacts. Evidence of climate-change impacts is strongest and most comprehensive for natural systems (Intergovernmental Panel on Climate Change [IPCC], 2014). Freshwater resources as a part of the ecosystem would also change with future climate changes. For example, changes in surface and ground water, floods and droughts, the water quality, erosion and sediment transport in the low-lying areas can occur (IPCC, 2012; Barragan \& Geraldi, 2018). Some physical and biological systems in many parts of the world have already changed due to past regional changes in climate (Tezcan et al., 2019).

The shallow lakes are highly sensitive to precipitation and temperature variability, and they also influence in the and drainage basin characteristics (Monti and Escofet, 2008; Schröter et al., 2005; Milly, Dunne, and Vecchia, 2005; Adrian, Wilhelm, and Gerten, 2006; Palmer et al., 2008; Erler et al., 2019). Studies of lakes are good early indications of the effects of current climate change on ecosystem structure and function (Adrian et al., 2009; Magnuson et al., 2000; Verburg, Hecky, and Kling, 2003; Jeppesen, Søndergaard, and Liu, 2017). Few studies have been able to quantify lake- climate relationships with precision for individual lake (Barley et al., 2006; Coats, Perez-Losada, Schladow, Richards, and Goldman, 2006; Sun, Lu, Lin, and Wang, 2016; Fee, Hecky, Kasian, and Cruikshank, 1996; Geraldi, Piccolo, and Perillo, 2010; Jeppesen et al., 2009; Jones, McMahon, and Bowler, 2001; Peeters, Livingstone, Goudsmit, Kipfer, and Forster, 2002; Plumb and Blanchfield, 2009; Shi et al., 2007).

Changes in lake levels are determined primarily by changes in river inflows and outflows, type and total amount of precipitation on to the lake, and evaporation from the lake (Kundzewicz, Mata, Arnell, Doll, and Kabat, 2007; Vincent, 2009). The percentage of the surface water and the groundwater however are controlled mainly by precipitation and evapo-transpiration. Water resources which have a shorter residence time are more vulnerable to climate changes than those with a longer residence time (Ekmekci $\&$ Tezcan, 2006; Jeppesen et al., 2009).

Floods and droughts are another important factor to consider when climate changes and climate variability increases. Floods depend on precipitation intensity, volume, timing, past conditions of rivers and their drainage basins. Anthropogenic activities on the flood plains and lack of flood response plans increase the damage potential (Londoño, Martinez, and Massone, 2012; Salvia, Karszenbaum, Kandus, and Grings, 2009). Most model projections show that higher precipitation extremes in warmer climates are very likely to occur. Precipitation intensity increases almost everywhere, but particularly at mid- and 
high latitudes where mean precipitation also increases, which will have a direct effect on the floods in the areas. Conversely, mid- and low latitude continental interiors are likely to experience droughts during summer months (Kundzewicz et al., 2007).

One-sixth of the earth's population is dependent on the melt water from glaciers and seasonal snow packs for their water supply. Many small glaciers will disappear in the next few decades and drought problems are therefore projected for regions that depend heavily on this melt water (Shi et al., 2007). At the same time rapid glacial retreat can lead to flooding of rivers and formation of glacial melt water lakes posing a threat to the population in the area (Kundzewicz et al., 2007). The Andean inter-tropical glaciers are very likely to disappear over the next decades, affecting water availability and hydropower (Magrin et al., 2007).

The objetives at this work is to demostrate the change shallow lake size over a period of 20 years and to relate it to temperature and precipitation over de basin area for the same time period. It is also intended to examine future temperature and precipitation scenarios over study area, and determine the risk of flood or drought within a 100 year period, from 2000 to 2099. Finally to connect and compare different climate sources and model simulations for the region.

\section{Methodology}

\subsection{Study area}

Las Encadenadas del Oeste consists of 5 shallow lakes (Epecuén, Venado, Del Monte, Cochicó and Alsina) of various depth and size, and is a closed river basin system lined up in an east-west direction. The system is located in the Buenos Aires province $\left(37^{\circ} 10^{\prime} \mathrm{S}, 62^{\circ} 50^{\prime} \mathrm{W}\right)$ which occupies an area of $302,650 \mathrm{~km}^{2}$ (Figure 1). The drainage basin of Las Encadenadas del Oeste has an area of 1,115,248 hectares and lies on a mean altitude of 100 meters above sea level (Geraldi, 2009).

Figure 1. Study area

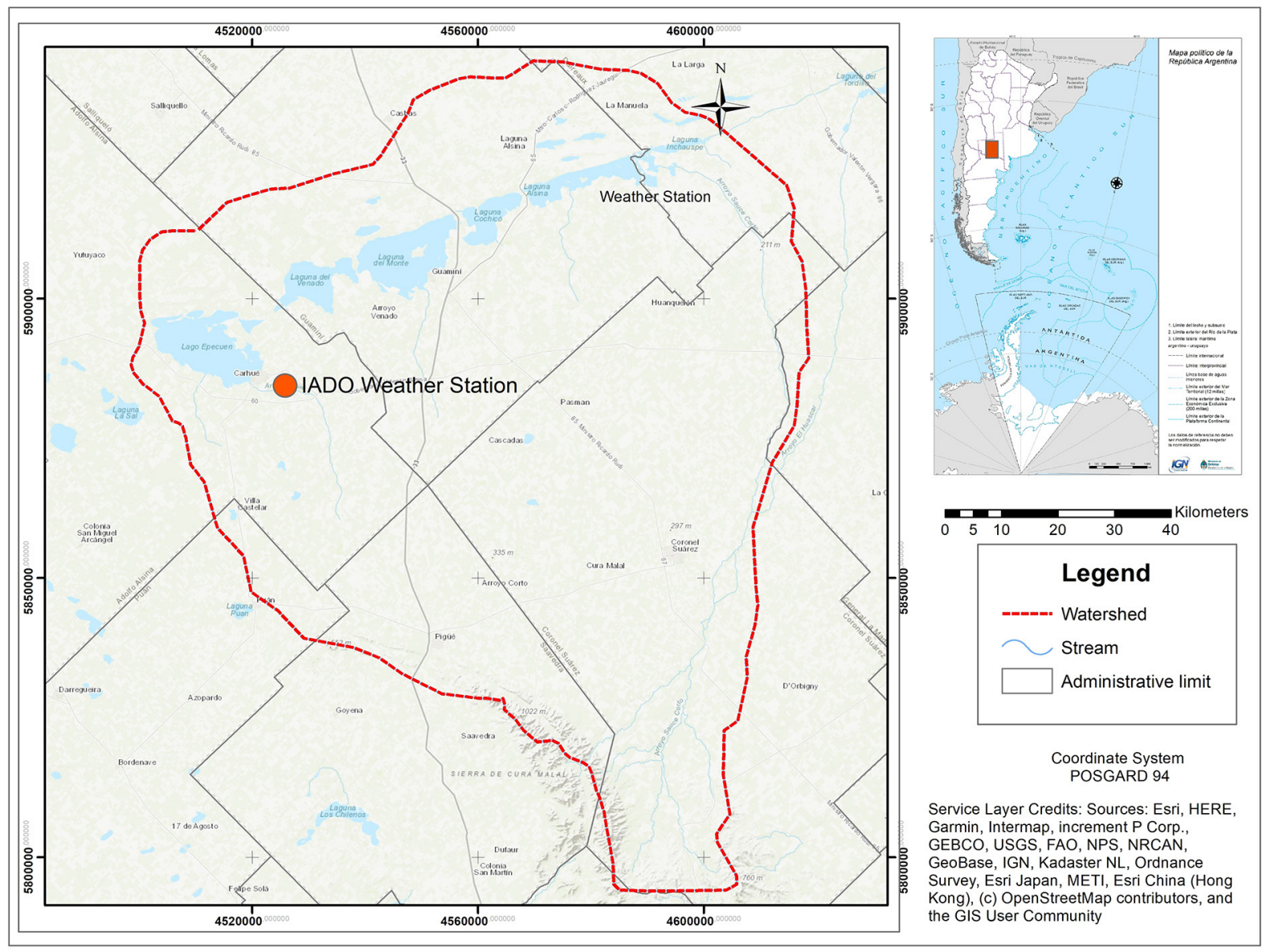

Own Elaboration 
The ponds are shallow and have no thermal stratification (Geraldi, 2009). Anthropogenic activities such as farming, cattle rearing and industrial activities are present in the area, and the ecosystem withstands strong impacts from these activities (Geraldi, 2009). Previous studies (Quirós, 2000; Bauer, Del Genio, and Lanzante, 2002) have shown that Las Encadenadas del Oeste are eutrophic. The levels of nitrogen, phosphorous and chlorophyll A are high, which helps both biomass and phytoplankton production to reach substantial levels. Epecuén shallow, which also is considered to be a salt lake, has extremely high levels of phosphorous and is therefore hypereutrophic (Geraldi, 2009).

The shallow lake were created during long periods of droughts millions of years ago, and the lowest part of the depression system is occupied by Epecuén ponds in the west which is the largest one and which drains all the excess water. It lies on a mean altitude of 90 meters above sea level. The shallowest lake is Alsina with only 3 meters depth in the east and then the depth increase towards the west. Alsina lies on a mean altitude of 110 meters above sea level. Del Monte has a maximum depth of 5 meters, and towards the centre of the ponds is an island which has an area of 400 hectares and which is used for tourism and agriculture. Epecuén, the largest shallow lake, has a maximum depth of 8.5 meters in the centre, but a medium depth of 7 meters. The smallest ponds in the area is Cochicó (Figure 3). The area and perimeter of the shallow lakes vary with precipitation and evaporation changes. The occurrence of floods and droughts are frequent and varies with climate variation in the area (Geraldi, 2009).

\subsection{Climate datasets}

Maximum and minimum temperature data and precipitation data from 1994 to 2017 was retrieved from a climate station in Carhué (station 4992 from IADO), which is a village southwest of Epecuén (Figure 3). Annual mean temperature and precipitation was calculated. Monthly mean temperature and precipitation for the period 1994 to 2017 was created from the station data to see how much it varies within a year.

Historical temperature and precipitation data was downloaded from Climate Explorer on Koninklijk Nederlands Meteorologisch Instituut (KNMI) (KNMI, 2008). First temperature and precipitation data from CRU TS 2.1 from 1901 to 2002 was downloaded. The CRU TS 2.1 Global Climate Dataset is comprised of 1224 monthly time-series of climate variables, for the period 1901-2002, covering the global land surface, excluding Antarctica, at 0.5 degrees resolution (CGIAR-CSI). The temperature CRU TS 2.1 data was extracted for the region $37^{\circ} \mathrm{S} 37.5^{\circ} \mathrm{S}$ and $62^{\circ} \mathrm{W}-62.5^{\circ} \mathrm{W}$. Since precipitation data varies more in this area than the temperature data, a larger area was selected to get a better picture of the total precipitation over the drainage basin. The area covered by CRU TS 2.1 dataset for precipitation is $36^{\circ} \mathrm{S}-38^{\circ} \mathrm{S}$ and $61^{\circ} \mathrm{W}-63^{\circ} \mathrm{W}$ which is representative of the whole drainage basin.

Since the CRU TS 2.1 dataset only contains data until 2002, data from an additional source was collected as well. The "CPC GHCN/CAMS t2m analysis" was used for temperature, and it contains data for all months from 1948 until 2005. It extracts the same region as the CRU TS 2.1 temperature dataset. CPC GHCN/CAMS is the combined analysis of the Global Historical Climatology Network dataset and the Anomaly Monitoring System. The CHCN was released in 1997 and has more than 30 diverse data sources and up to 7,280 stations globally. The CAMS was designed to monitor the initiation and evolution of significant land surface parameter anomalies with high quality, near real time observations and sufficient long historical records. The CAMS dataset has up to 6,158 stations globally with station observations based on two data sources, one from NCAR (National Center for Atmospheric Research) for the period before 1981 and another from GTS (Global Telecommunication System) for the period after 1981 (Fan $\&$ van den Dool, 2008).

Precipitation data was also downloaded from the CPC Merged Analysis field. This field cuts out a larger region $\left(35^{\circ} \mathrm{S}-37.5^{\circ} \mathrm{S}\right.$ and $\left.60^{\circ} \mathrm{W}-62.5^{\circ} \mathrm{W}\right)$ than the CRU TS 2.1 data set and might not be as representative for the area. The CPC Merged Analysis of Precipitation ("CMAP") is a technique which produces pentad and monthly analyses of global precipitation where observations from rain gauges are combined with precipitation estimates from several satellite-based algorithms (infrared and microwave) (NOAACPC). A comparison between the two downloaded models and the station data was performed to establish how well they correlate.

\subsection{Satellite images}

15 satellite images from Landsat 5 TM; Landsat 7 EMT and Landsat 8 OLI of the shallow lake were retrieved from CONAE (Comisión Espacial de Actividades Espaciales) from 1997 to 2017. The satellite 
images were atmospherically corrected with the image analysis extension. Flash model was used for atmospheric correction. The FLAASH model includes a method for retrieving an estimated aerosol/haze amount from selected dark land pixels in the scene. The method is based on observations by Kaufman, Wald, Remer, Gao, Li, and Flynn (1997) of a nearly fixed ratio between the reflectance for such pixels at $660 \mathrm{~nm}$ and $2100 \mathrm{~nm}$.

FLAASH calculates the spectral radiance at a sensor pixel, L, that applies to the solar wavelength range (thermal emission is neglected) and flat, Lambertian materials or their equivalents (Equation 1):

$$
L=\left(A p /\left(1-p_{-}(e) S\right)\right)+\left\lfloor\left(B p_{-} e\right) /\left(1-p_{-}(e) S\right)\right\rfloor+L_{a}
$$

Equation 1

where:

$\mathrm{p}$ is the pixel surface reflectance; $p_{e}$ is an average surface reflectance for the pixel and a surrounding region;

$\mathrm{S}$ is the spherical albedo of the atmosphere; $\mathrm{L}_{\mathrm{a}}$ is the radiance back scattered by the atmosphere; $A$ and $B$ are coefficients that depend on atmospheric and geometric conditions but not on the surface.

The values of A, B, S and La are determined from MODTRAN4 calculations that use the viewing and solar angles and the mean surface elevation of the measurement, and they assume a certain model atmosphere and aerosol type. The reflectance was calculated with the equation 2:

$$
L_{e}=\left((A+B) p_{e} \mid 1-p_{e} S\right)+L_{a}
$$

Equation 2

$L_{e}$ spatially averaged radiance image;

The images were imported to Arc GIS 10.1, and the shallow lakes were digitalized. The shallow lake area was estimated by Arc GIS for each pond, and the change in area from year to year calculated. Water that after dry years created ponds separated from the shallow lake were not included in the calculation of the total pond area.

Rainfall patterns in the area vary considerably between summer and winter. Therefore, to be able to compare the shallow lakes area to relevant precipitation and temperature data, a mean of the climate variables was created for periods of 6 and 12 months before the image was taken. Station precipitation and temperature data was used to calculate these mean values. Nicholson (1999) found that water levels in Lake Tanganyika and Lake Rukwa, Tanzania, rose as precipitation in the catchment area increased, with a time lag of 1 to 3 years. Since these lake basins are larger than the basin for Las Encadenadas a shorter time period was adopted.

\subsection{Statistical analysis}

Statistical analysis was done using the ordinary least squares (OLS) method (Burnham, and Anderson, 1998), multiple regression analysis was conducted using SPSS v.12 to estimate the relationship between lake area and the climate variables for each of the shallow lakes. The regression model (Equation 3) used was:

$$
\begin{aligned}
& \text { Area }=\beta \_0+\beta \_(1) X \_1+\beta \_(2) X \_2 \ldots \ldots+\beta \_(n) X \_n+\epsilon \\
& \text { Area }=\beta 0+\beta 1 \mathrm{X} 1+\beta 2 \mathrm{X} 2+\ldots \ldots \ldots+\beta \mathrm{n} \mathrm{Xn}+\epsilon
\end{aligned}
$$

Equation 3

where Area is the pond area estimated by ArcGIS (dependent variable)

$\beta 0$ is a constant

$\beta 1, \beta 2, \ldots, \beta \mathrm{n}$ are regression coefficients

$\mathrm{x} 1, \mathrm{x} 2, \ldots \mathrm{xn}$ are explanatory variables

$\epsilon$, is an error term

The independent explanatory variables were maximum, minimum and mean temperatures 6 and 12 months before images were recorded; and precipitation 6 and 12 months before.

Five OLS models were estimated by separately regressing pond area against the explanatory variables for each of the shallow lake. The sample size for each model was 14. Data for November 2004 was excluded from the analysis since it was considered an outlier. Tukey's method was used to calculate outliers.

The best-fitting OLS model was established using the stepwise method in SPSS. The first regression run for each model found that the most significant explanatory factor in influencing shallow lake area 
was one of the temperature variables. On the second regression run, only the most significant temperature variable and the two precipitation variables were included.

\subsection{Future scenarios and Model comparison}

The IPCC has in the "Special Report on Emission Scenarios" listed 4 different emission scenarios (A1, A2, B1 and B2) depending on different outlooks for the future. Two of them (A2 and B2) were used (IPCC, 2000).

The A2 storyline and scenario family describe a very heterogeneous world. The underlying theme is self-reliance and preservation of local identities. Fertility patterns across regions converge very slowly, which results in continuously increasing global population. Economic development is primarily regionally oriented and per capita economic growth and technological change are more fragmented and slower than in other storylines.

The B2 storyline and scenario family describe a world in which the emphasis is on local solutions to economic, social, and environmental sustainability. It is a world with continuously increasing global population at a rate lower than A2, intermediate levels of economic development, and less rapid and more diverse technological change than in the B1 and Al storylines. While the scenario is also oriented towards environmental protection and social equity, it focuses on local and regional levels.

Future monthly precipitation and temperature anomalies for the A2 and B 2 scenarios for the HADCM3 model were downloaded from Climate Explore on KNMI. The model extracts region has data from 1950 to 2099. The downloaded date included corrected anomalies from 1950 and 1990. Annual means were calculated from 2000 to 2099 from precipitation and maximum and minimum temperature, and change was then calculated for the 100 year period from 2000 to 2099.

A model comparison was made to see how the data downloaded for the HadCM3 model is explained by other models. Future estimated precipitation in the area for scenario A2 from IPCCs SRES scenarios was downloaded from Climate Explorer. Total annual precipitation for four models; ECHAM4/OPYC, GFDL, HadCM3 and NCAR-CSM was calculated to see the differences among different models. The four models have different time spans. The ECHAM4/OPYC model data was available from 1990 to 2100; the GFDL 1961 to 2100; HadCM3 model 1950 to 2099 and the last model used NCAR-CSM data available from 2000 to 2099 (KNMI, 2018).

\section{Results}

Station temperature data showed generally higher temperatures than the model data. Station data and model data were moderate correlated in the temperature data $(r=0.41)$. Station data showed variations of $1{ }^{\circ} \mathrm{C}$ from $15-16{ }^{\circ} \mathrm{C}$ in the mean temperature data over the 12 year period. The two model datasets show a better correlation $(\mathrm{r}=0.66)$ and have a temperature variation between 14.4 and $15.5^{\circ} \mathrm{C}$ (Figure 2).

Figure 2. Comparison between station temperature data in Carhué and models temperature data

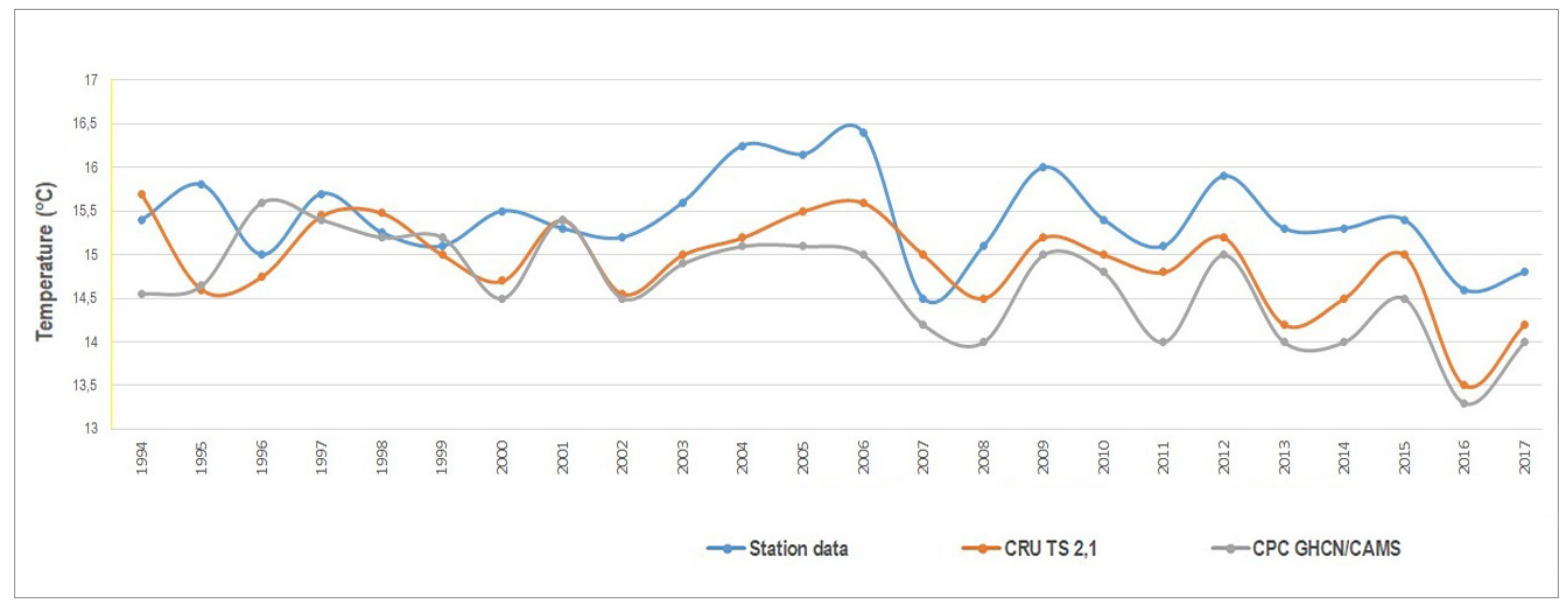

Own elaboration 
Precipitation data shows a clearer link between station data and downloaded historical observations than the temperature data. Even though the station data has larger variations in amount of precipitation, all twelve years are quite well correlated with the downloaded data. The station dataset however shows a lot less precipitation than the downloaded dataset. Precipitation range from the station data is between $285-955 \mathrm{~mm}$, and the downloaded data showed a variation between $722-1,235 \mathrm{~mm}$. Even though it illustrated more precipitation, the CPC Merged Analysis data has more similarities to the station data than the CRU TS 2.1 dataset in terms change in rainfall (Figure 3).

Precipitation anomalies from 1994 to 2017 from the station data in Carhué show that precipitation varies considerably between year; and even though the period is a dry decade within a humid period, some peaks in the precipitation data can explain the high precipitation when calculated annually (Figure 4).

Figure 3. Comparison in mean annual precipitation between station data in Carhué and models data

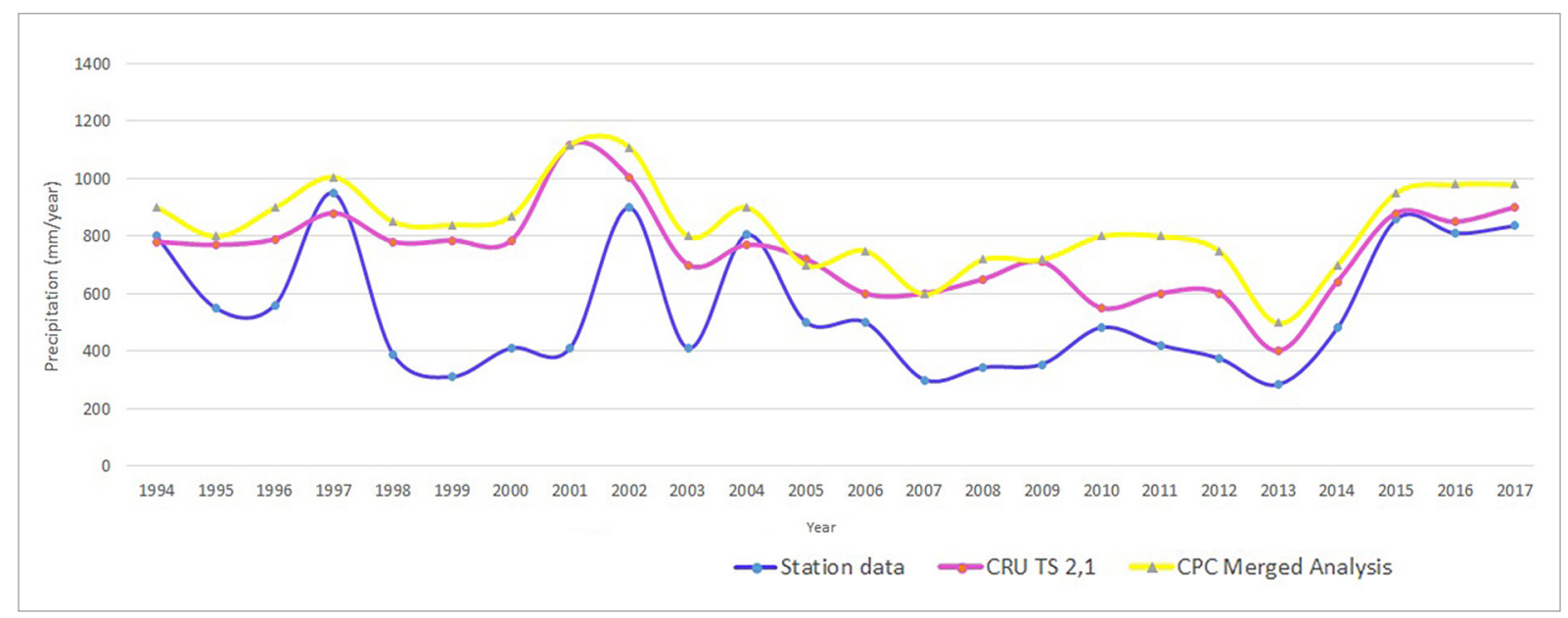

Own elaboration

Figure 4. Precipitation anomalies from 1994 to 2017. Data from station in Carhué

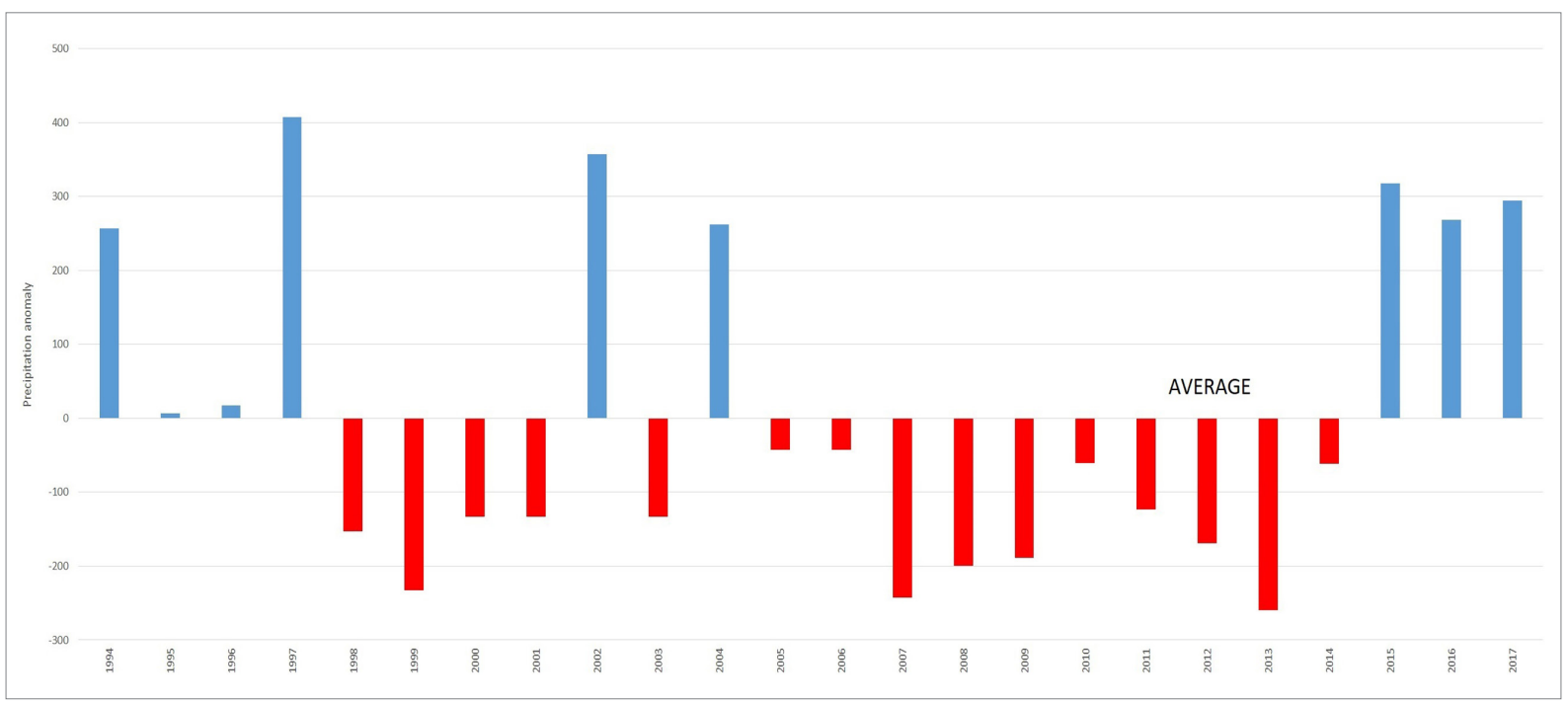

Own elaboration

Whith regard to satellite images the shallow lake area was calculated. It can be seen in Figure 5 that the fluctuation between the areas in the five shallow lake is consistent throughout the entire study period. The greatest fluctuation in area is observed in the larger shallow lake (Epecuén, Del Monte and Alsina).

Precipitation and temperature patterns over the 12 month period before capture of the satellite images were analyzed to see the actual response from the climatic variables. Generally, there is a good correlation 
(between mean precipitation calculated for the 12 month period before images were recorded and shallow lake area. When precipitation increases, the pond area increases as well. This pattern is however not seen in 1998, 2001, 2003 and 2005 (Figure 6).

Figure 5. Area of Epecuén, Venado, Del Monte, Cochicó and Alsina calculated from the Landsat images from 1997 to 2017

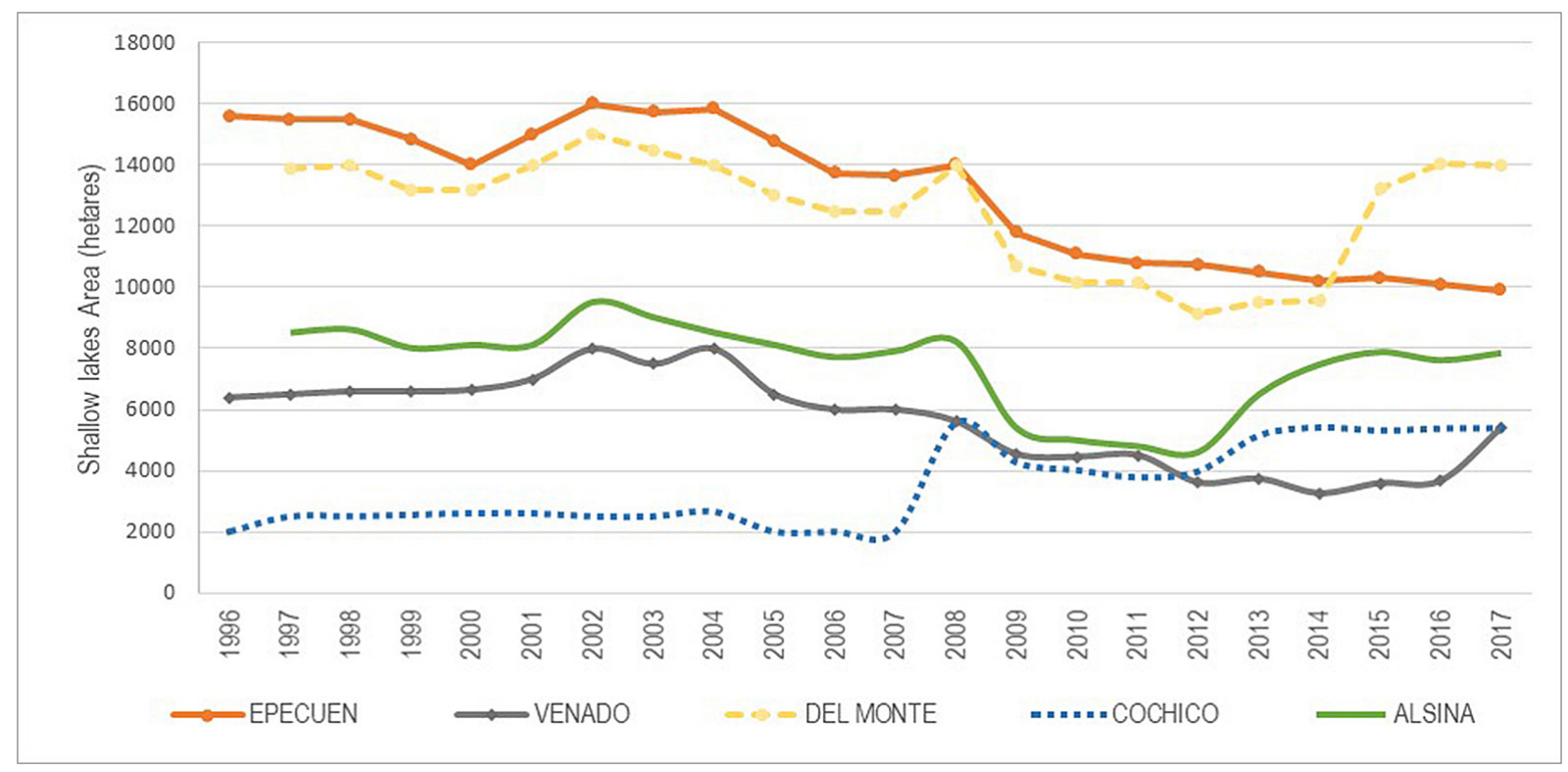

Own elaboration

According to the diagram with maximum and minimum temperature calculated over the 12 months before images were recorded, there is generally an inverse relationship between pond area and temperature. These trends are however not very clear. In many occasions maximum temperature decreases when the minimum temperature increases (Figure 7).

Figure 6. Shallow lake area and mean precipitation calculated 12 months before the images were taken

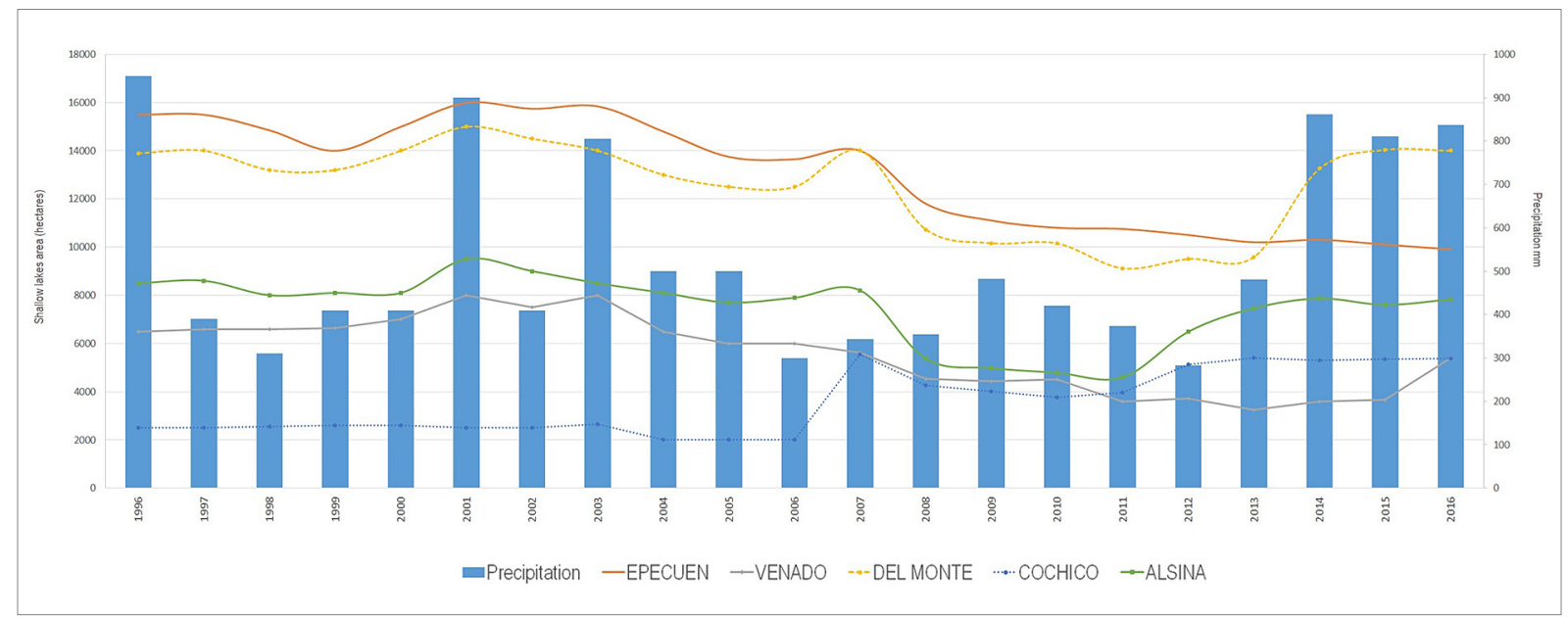

Own elaboration

In the OLS multiple regression analysis the samples consisted of data recorded from 14 different periods. November 2004 was considered an outlier and was therefore removed from the regression analysis. Figure 8 describes how ponds area increases as mean temperature increases. If, however the outlier in November 2004 is removed the results show different and more expected results, since shallow lake area was anticipated to decrease as temperature rises. 
Figure 7. Shallow lake area and maximum and minimum temperature calculated 12 months before the images were taken

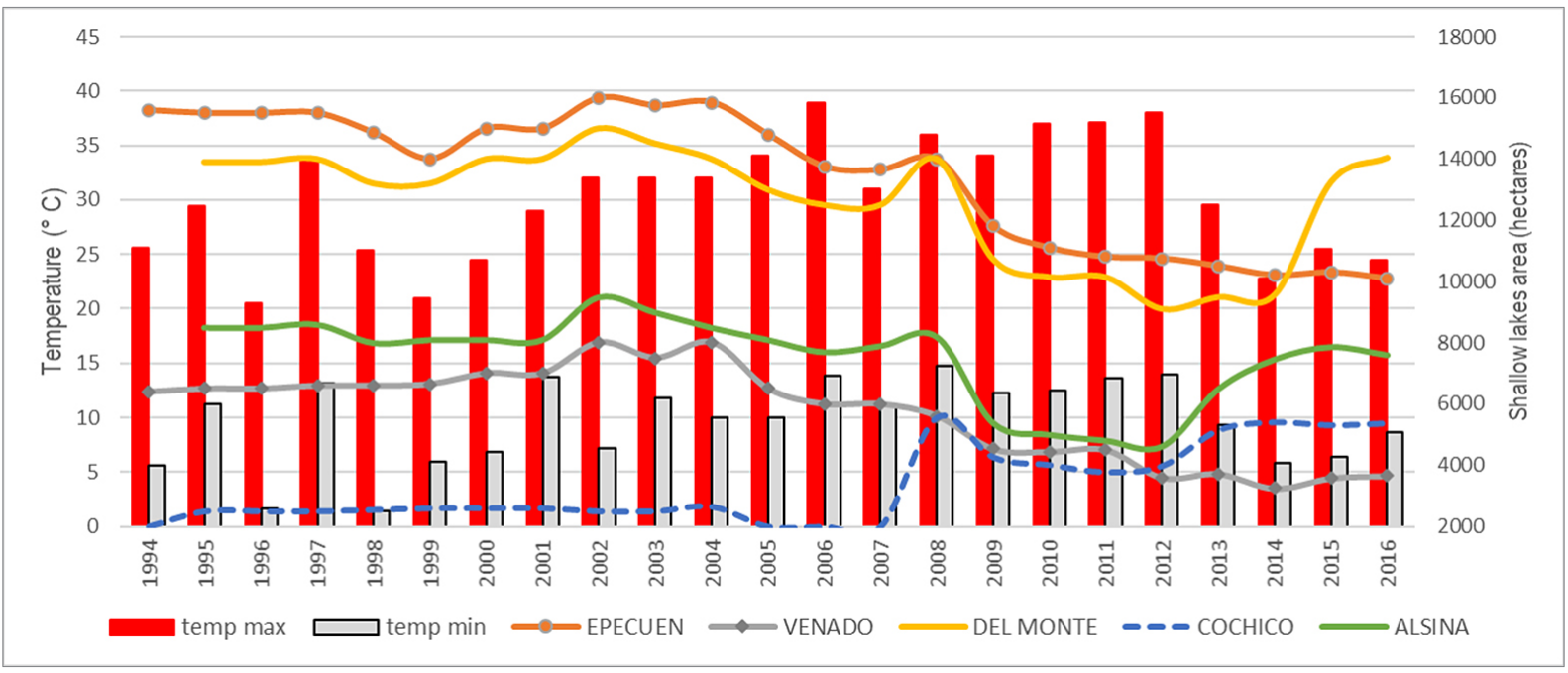

Own elaboration

A scatter plot with the area of Epecuén and mean temperature was done. Only Epecuén area was chosen here but the other four shallow lakes showed the same trend in an increase in area during November 2004 (Figure 8).

Figure 8. Scatter plot with the area of Epecuén and mean temperature from 1997 to 2006 showing the outlier in November 2004. If the outlier is removed from the plot a declining trend in area is seen as temperature rise

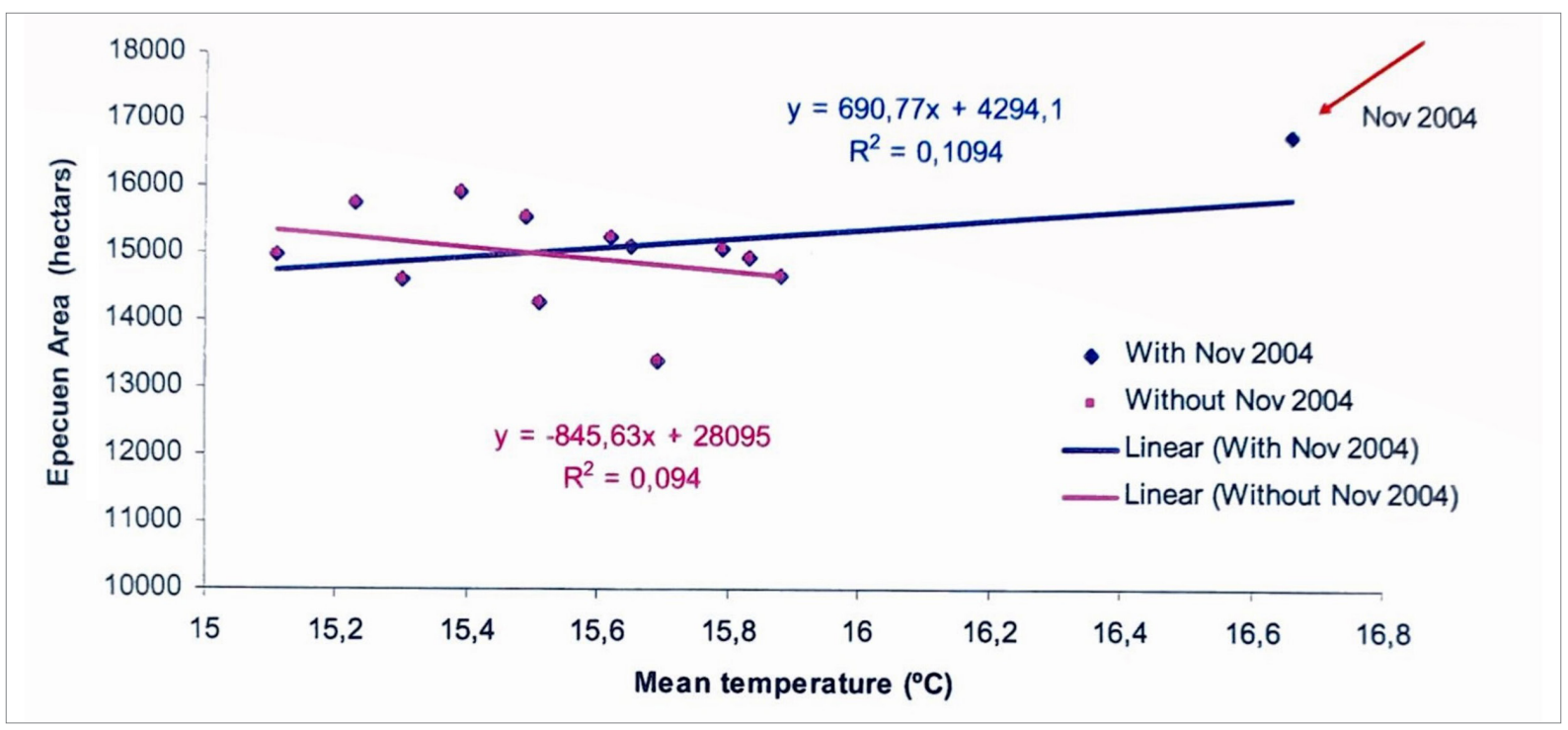

Own elaboration

The best- fitting OLS models for five shallow lake are described in table 1. The results of the regression analysis showed that:

- Temperature is a more significant explanatory factor than precipitation.

- Temperature was significant with a p value less than 0,1 for four models (Epecuen, Del Monte, Alsina y Venado).

- Precipitation was significant with a p value less than 0,1 for Alsina only.

- Precipitation was not significant for Venado and Cochico.

- In the case of Epecuen, Del Monte and Alsina, temperature is less significant when describing area on it own than when combined with precipitation.

- Maximum temperature was not significant for any of five models. 
Table 1. The OLS model for Epecuen. Venado, Del Monte Cochicó and Alsina

\begin{tabular}{|c|c|c|c|c|}
\hline & Regression coefficient & Std. Error & Significance & \\
\hline \multicolumn{5}{|l|}{ Epecuen } \\
\hline Constant & 23233,11 & 4160,82 & 0 & \\
\hline $\mathrm{T}$ min & $-914,48$ & 435,62 & 0,065 & \\
\hline $\mathrm{P}$ & 14,22 & 8,24 & 0,11 & $\mathrm{R}^{2}=0,41$ \\
\hline \multicolumn{5}{|l|}{ Venado } \\
\hline Constant & 19726,02 & 6279,78 & 0,01 & \\
\hline $\mathrm{T}$ mean & $-820,81$ & 404,04 & 0,07 & $\mathrm{R}^{2}=0,30$ \\
\hline \multicolumn{5}{|l|}{ Del Monte } \\
\hline Constant & 23057,12 & 4932,23 & 0,001 & \\
\hline $\mathrm{T} \min$ & $-1002,38$ & 516,38 & 0,084 & \\
\hline $\mathrm{P}$ & 13,17 & 9,77 & 0,211 & $\mathrm{R}^{2}=0,32$ \\
\hline \multicolumn{5}{|l|}{ Cochico } \\
\hline Constant & 7684,9 & 1643,57 & 0,001 & \\
\hline $\mathrm{T} \min$ & $-260,81$ & 166,59 & 0,149 & $\mathrm{R}^{2}=0,20$ \\
\hline \multicolumn{5}{|l|}{ Alsina } \\
\hline Constant & 29910,19 & 11860.45 & 0,033 & \\
\hline $\mathrm{T}$ mean & $-1440,56$ & 774,76 & 0,096 & \\
\hline $\mathrm{P}$ & 15,22 & 8,2 & 0,096 & $\mathrm{R}^{2}=0,35$ \\
\hline
\end{tabular}

Own elaboration

Both A2 and B2 scenarios showed an increase in precipitation within a 100 year period from 2000 to 2099 using the HadCM3 model, although the variation is very high. The change in precipitation in the A2 scenario is $0.25 \mathrm{~mm}$ and in the B2 scenario only $0.04 \mathrm{~mm}$. The variation is larger than the change and stretches between -0.6 to $1 \mathrm{~mm}$ in the A2 scenario. In the B2 scenario the variation stretches between -0.5 to $1.1 \mathrm{~mm}$. The total mean variation shows in other words a span of $1.6 \mathrm{~mm}$ precipitation anomaly. In other words, the variation in the data can be up to about $600 \mathrm{~mm}$ (Figure 9).

Figure 9. Future precipitation anomalies from 2000 to 2099 with scenarios A2 and B2 from IPCCs TAR

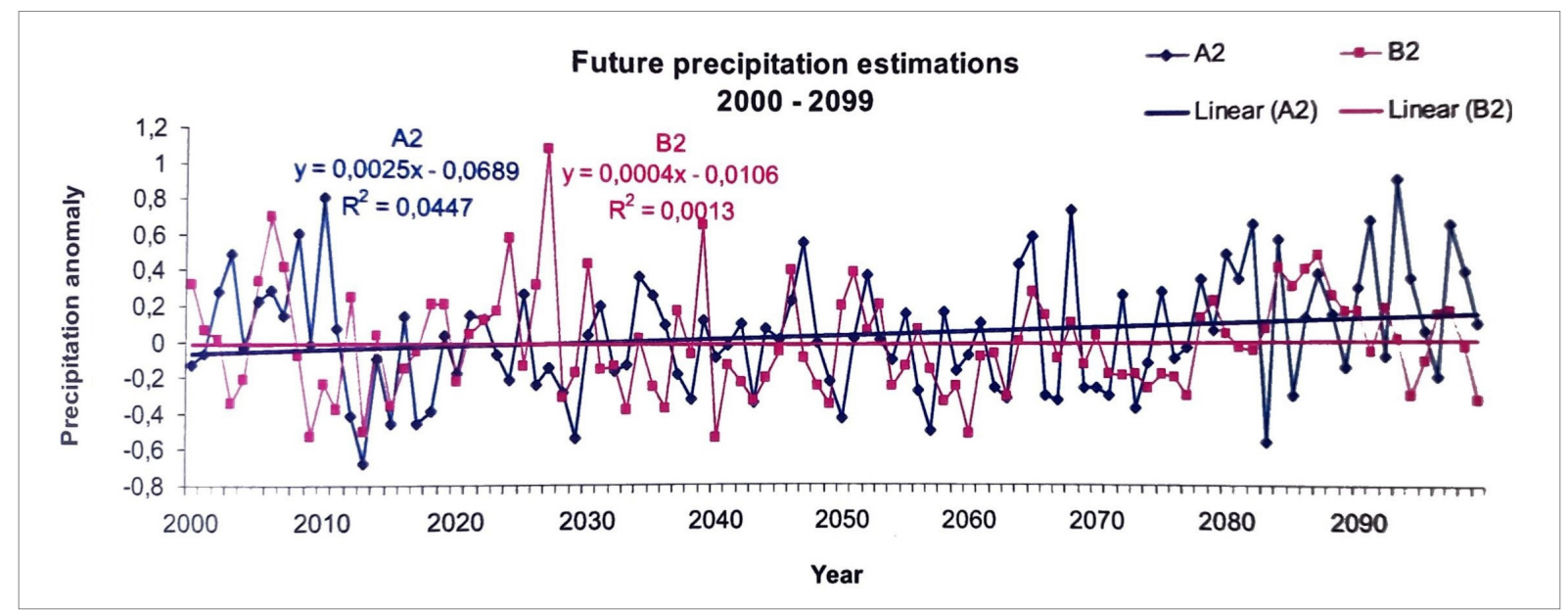

Own elaboration

In the future maximum temperature estimations, the increase from 2000 to 2099 was $3.37^{\circ} \mathrm{C}$ in the A2 scenario and $2.37^{\circ} \mathrm{C}$ in the B2 scenario. The variation in the data is however quite high (Figure 10).

In the future minimum temperature estimations, the increase from 2000 to 2099 was $3.75^{\circ} \mathrm{C}$ in the A2 scenario and $2.31{ }^{\circ} \mathrm{C}$ in the B2 scenario. The A2 scenario therefore shows a higher increase in both maximum and minimum temperatures. Variation in the data is less than in the estimations for maximum temperature (Figure 11). 
Figure 10. Future maximum temperature anomalies from 2000 to 2099 with scenarios A2 and B2 from IPCCs TAR

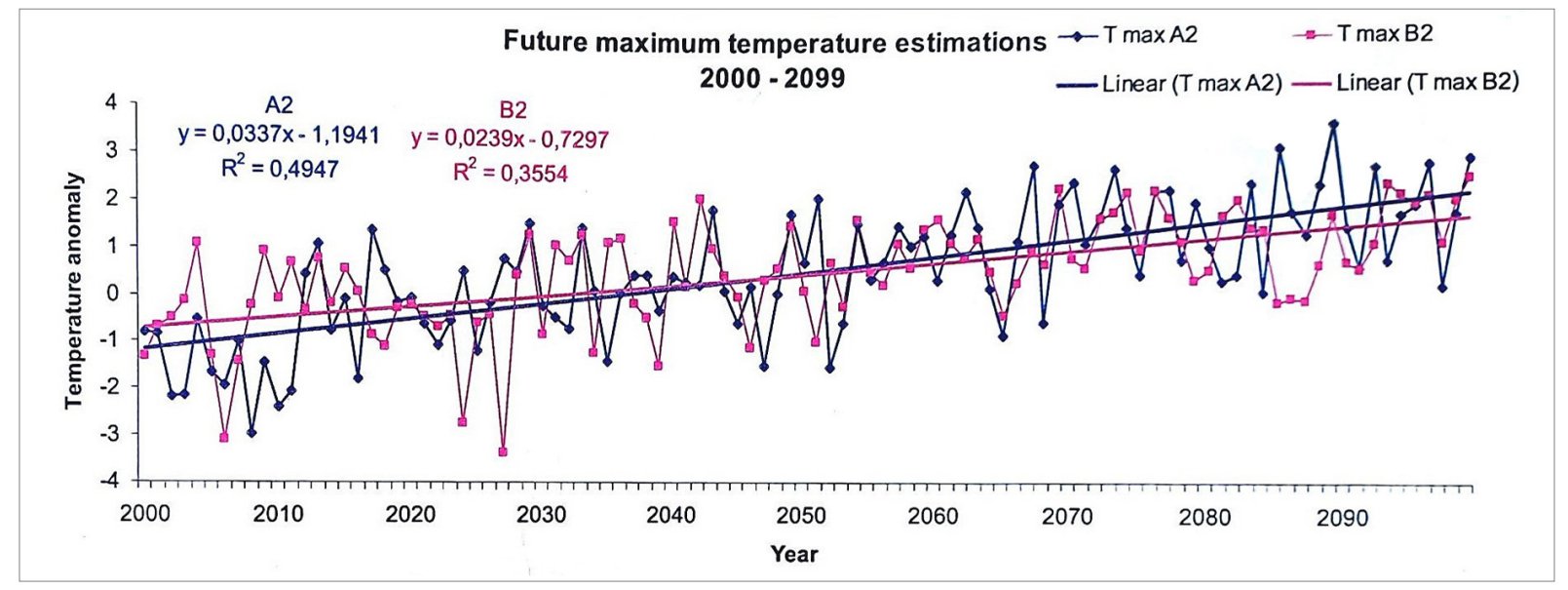

Own elaboration

Figure 11. Future minimum temperature anomalies from 2000 to 2099 with scenarios A2 and B2 from IPCCs TAR

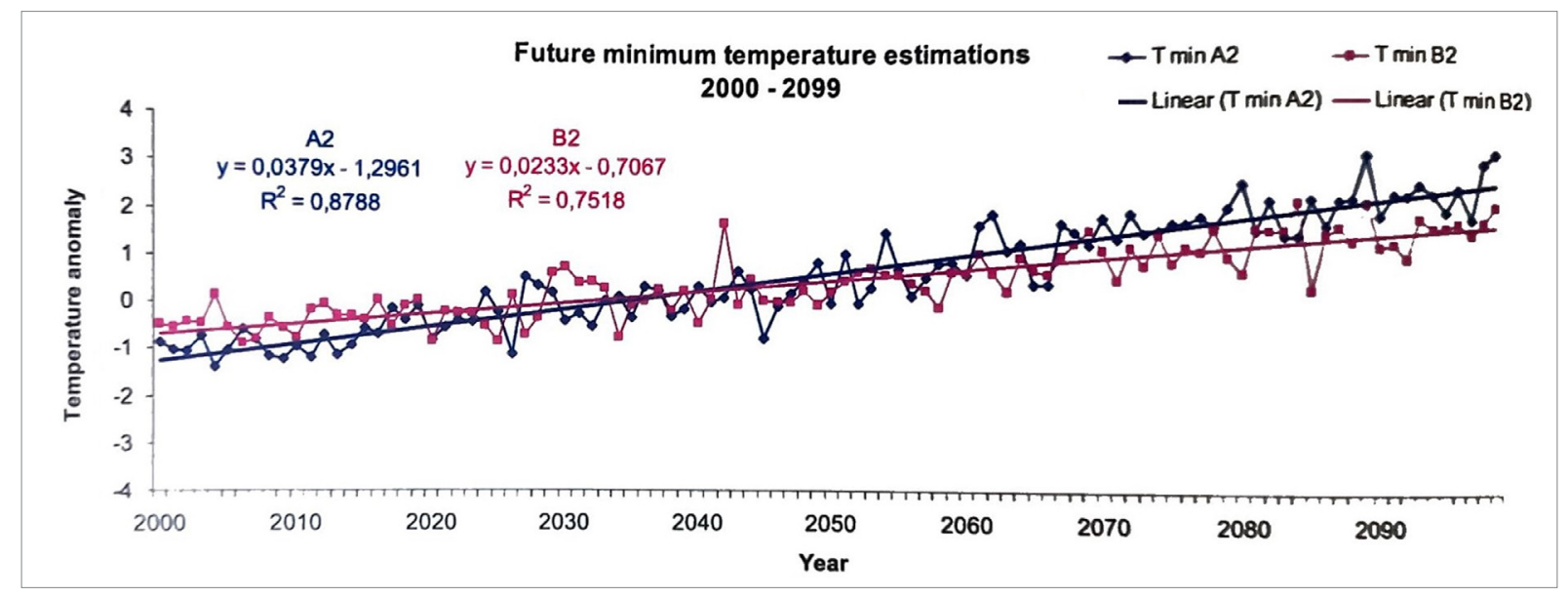

Own elaboration

Figure 12. Comparison between the model HadCM3 used in the analysis above and three other models; ECHAM4/OPYC, NCAR-CSM and GFDL.3.1. Subsection

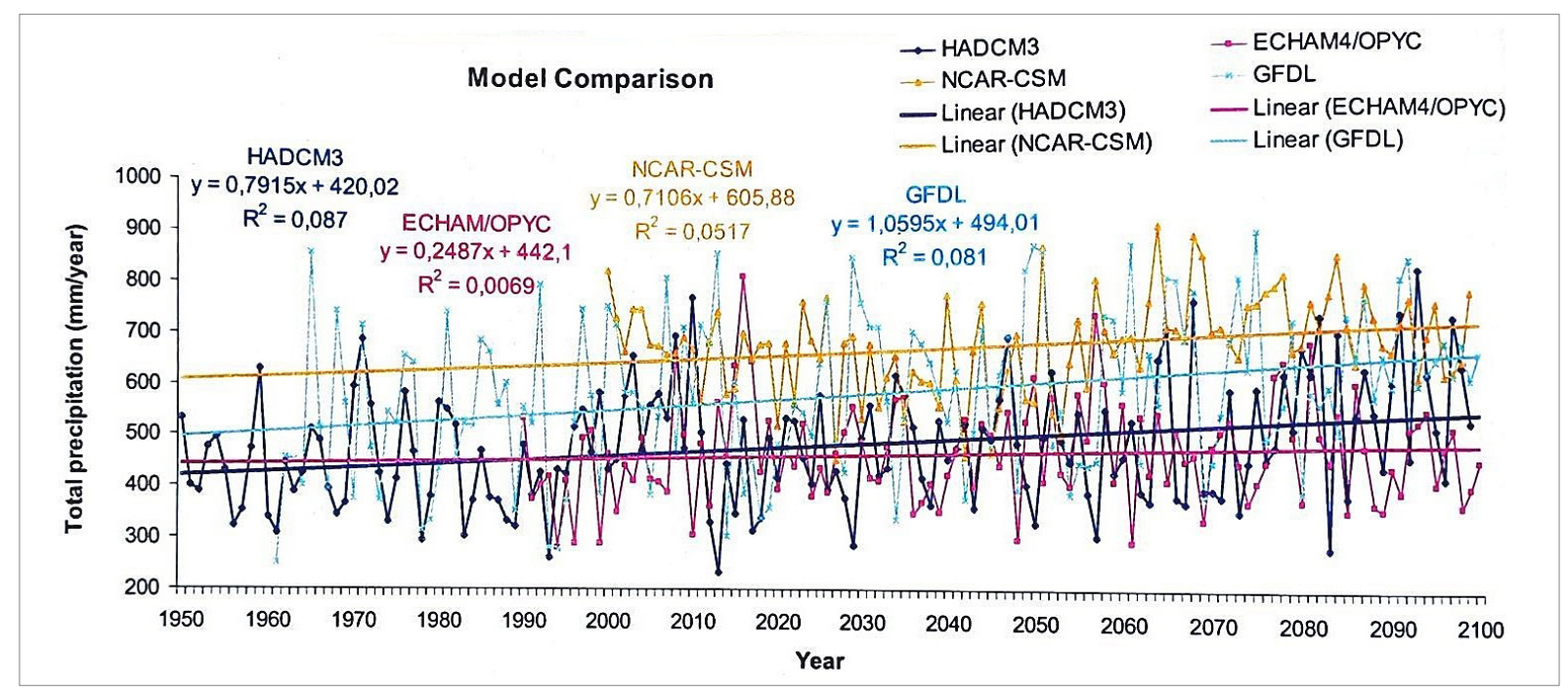

Own elaboration 
To see more or less how well the HadCM3 model explains future change, a comparison was made with 3 other models which also use the A2 scenario. As can be seen in figure 12 the HadCM3 model shows lower precipitation from the beginning than all the other models, and the net change from 1950 to 2099 was estimated to be $119 \mathrm{~mm}$. The lowest increase in temperature is seen in the ECHAM/OPYC model with a change of only $37.3 \mathrm{~mm}$. The NCAR-CSM model begins with higher temperatures than the other models, and the change in the 150 year period is $106.6 \mathrm{~mm}$. The GFDL model have values between the others and shows the highest change in precipitation with an increase of $158.9 \mathrm{~mm}$ (Figure 12).

\section{Discussion}

Temperature data from the meteorological station and downloaded temperature data are not very good correlated from year to year, and they differ in around $0.5^{\circ} \mathrm{C}$ to $1{ }^{\circ} \mathrm{C}$ throughout the whole period from 1994 to 2006. When mean was calculated from 1994 to 2002 for all three data sources the change between station data and the downloaded data was $0.5^{\circ} \mathrm{C}$, with station data showing higher temperatures. The station data and downloaded data are in the case of precipitation quite good correlated from year to year, which is good since precipitation varies a lot from east to west in the study area. Station data however shows 200 to $400 \mathrm{~mm}$ less precipitation per year than the downloaded data, which probably is because the downloaded data covers a region which is bigger than the basin for the study area. Station data shows a mean of $600 \mathrm{~mm}$ per year when calculated from 1994 to 2002, while the CRU dataset has a mean of $850 \mathrm{~mm}$ per year and the CPC dataset has a mean of $1000 \mathrm{~mm}$ per year. Station data shows $40 \%$ less precipitation than the CPC data and $30 \%$ less precipitation than the CRU data. These differences observed between the two datasets are important to keep in mind when using models to predict climate scenarios for the future.

The mean monthly precipitation in summer (DJF) is a lot higher than during the winter months (JJA). Temperature is also higher during the summer and more water will evaporate even though it rains more. There could however be a delay in response of ponds water levels from precipitation. The shallow lake will respond to these changes in precipitation and temperature with a fluctuating water level.

The study area presented a significant rainfall variability with alternating dry and wet period (Barragan and Geraldi, 2018; Casado y Campo, 2019; Aliaga, 2020). In the end of 2001 and 2002 it rained a lot in the area, and the shallow lake started to increase early (Geraldi, 2009). The decrease in ponds area from 2002 to 2003, even though precipitation increases, can be due to the early rise in area from the heavy rains and then an early response from the less precipitation in the latter half on 2002.

Apart from this, by looking at the size of the shallow lake with both temperature and precipitation data available there seems to be a connection between all three of them. Where shallow lake area can not be explained solely by precipitation patterns, the temperature data can explain what happens, and vice versa. It is therefore important to take into account not only one variable but both temperature and precipitation at the same time.

The reason why the water levels in the shallow lake do not correlate very well with precipitation data 6 months before the calculation of ponds area can be due to the time it takes for the water to reach the shallow lake from streams from the basin area. The lag time is longer than 6 months. The temperature data taken 6 months before the shallow lake area calculation showed correlation from 2003 to 2006 . The response from temperatures does not have the same lag time as precipitation and this might be reflected here.

Dangavs (2005), Torremorel, Bustigorry, Escaray, and Zagarese (2007), Allende et al. (2009); Bohn (2009) and Aliaga, Ferrelli, Alberdi-Algarañaz, Bohn, and Piccolo, (2016) showed that shallow lake dynamic depends mainly on precipitation. However, the statistical analysis does not take into consideration the behavior of a shallow lake basin in terms of lag times, openings and closings of dams, the geomorphology of the basins etc. The results however show that there is consistency in the data and that the shallow lakes behave in the same way. Why maximum temperature was never significant can be because the system answers more rapidly to evaporation already in small temperatures. The results also showed that the climate data calculated 12 months before the date that the images were taken were more significant then the 6 months data. This shows that the response time from the shallow lake is longer than 6 months.

Nicholson (1999) and Baigún, and Delfino (2003) showed that lakes and shallow lake have a response time of around 1 to 3 years. The reason why temperature is more significant then precipitation 
could be due to the time it takes for the shallow lake to respond to variations in precipitation. Precipitation and temperature were in this analysis calculated up to a year before the images were taken which can be a good estimation in response time for temperature. Precipitation might however have a more delayed response time. The reason why temperature is more significant than precipitation could be that the area has a continental climate and the study period from 1997 to 2006 is a dry period. From the 11 years in the study period, only 3 years had a lot of precipitation. Temperature turns therefore out to be more significant than precipitation.

Venado and Cochicó are the smallest lakes in area, and the level of significance for precipitation is a lot higher in these ponds than in the larger ones. They also do not have the same fluctuation in area as the larger shallow lake, and the reason for this is that they have a more vertical beach contour than the rest of them. The volume increases therefore but in the area calculation in the digitalizing process this can not be seen to the same extent due to the beach profile. Other studies have reached similar conclusions for example, Zunini, Ferrelli, and Piccolo, (2018); Alfonso, Brendel, Vitale, and Piccolo, 2020.

The variation in the data shows larger differences than the change in a 100 year period. Precipitation changes in the future are not as important as the variations from year to year. Climate models have before predicted an increase in precipitation over the area, but as shallow lake area is responding faster to the variation in the data, this is more important to consider. From 2001 to 2002 the precipitation increased almost $400 \mathrm{~mm} / \mathrm{year}$, and the water levels in the shallow lake increased a lot.

From future scenarios calculation it can be seen that the variation in the future will continue to vary in the same quantity. The A2 scenario shows a faster increase in precipitation than the B2 scenario due to the faster growing population and economic development in the A2 scenario and the more environmental friendly B2 scenario.

Even though temperatures are fluctuating quite a lot from year to year as well, they show a more rapid increase than the precipitation estimations for the future. The fast increase in temperature will affect the shallow lake more than the precipitation change. An increase in temperature will cause the evaporation from the shallow lake to increase as well and the area to decrease.

The water levels in the shallow lake will continue to fluctuate in the future as precipitation and temperature varies. Temperatures will increase fast in the area; around $3{ }^{\circ} \mathrm{C}$ change is expected until 2099. Only small variations in the temperatures have before caused shallow lake areas to change. Similar results were found for Quirós (2000) and Li et al. (2017). Precipitation patterns show a high variation, but the change is very small. Minimum temperature, which is already the most significant factor according to the statistical analysis, will in the future be an even stronger factor if changes occur.

The model comparison showed that the changes in precipitation explained by the HadCM3 model are intermediate in comparison to the others. The amount of precipitation is however lower in the HadCM3 model than as estimated by the other three models. Compared to the station data of precipitation the HadCM3 model has a good estimation of precipitation. The ECHAM4/OPYC model also shows precipitations in the same range. The other two models, NCAR-CSM and GFDL, show generally a higher precipitation range than the station data.

\section{Conclusions}

The precipitation data shows differences in $30-40 \%$ between station data and CRU TS 2.1 and CPC Merged Analysis data sets. Temperature shows differences of 3\% between the station data and the CRU TS 2.1 and CPC GHCN/CAMS data sets, with higher temperatures from the station data. All five shallow lakes respond together to the variations in temperature and precipitation. When precipitation increase and temperature decrease, shallow lakes areas generally tend to increase. With a higher increase in precipitation than normal, response can be seen in shallow lake area earlier than the time period required for normal conditions. This is very significant for flat regions with an abundance of ponds.

In the multiple regression analysis minimum temperature, mean temperature and precipitation when it was calculated 12 months before the images were taken were the most significant parameters for variations in shallow lake areas. And temperature was always more significant than precipitation. This constitutes the basis for future research in relation to the evapotranspiration of the shallow lake with different scenarios. 
Precipitation and temperature are together more significant than only temperature. Both precipitation and temperature will change in the future. For the case of precipitation in a 100 year period the variations are larger than the change, and might therefore be more important since the response in shallow lake area is relatively short.

The HadCM3 model predicts changes in precipitation which lies in between the other three models (ECHAM4/OPYC, NCAR-CSM and GFDL) and the precipitation range matches the precipitation collected from the station Carhue. The use of temperature and precipitation models and also future scenarios are useful tools for water resource management..

\section{Funding}

This work was carried out as a part of the project "Aplicación de Tecnologías de la Información Geográfica al estudio integral y comparativo de problemáticas ambientales. Segunda Parte(24/G089)", funded by the Universidad Nacional del Sur of Argentina.

\section{Acknowledgements}

We are thankful to Instituto Argentino de Oceanografía- CONICET are all acknowledged for their contributions to this work.

\section{References}

Adrian, R., O’Reilly, C. M., Zagarese, H., Baines, S. B., Hessen, D. O., Keller, ... \& Winder, M. (2009). Lakes as sentinels of climate change. Limnology and Oceanography, 54(6 PART 2), 2283-2297. https:// doi.org/10.4319/lo.2009.54.6_part_2.2283

Adrian, R., Wilhelm, S., \& Gerten, D. (2006). Life-history traits of lake plankton species may govern their phenological response to climate warming. Global Change Biology, 12(4), 652-661. https://doi. org/10.1111/j.1365-2486.2006.01125.x

Alfonso, M. B., Brendel, A. S., Vitale, A. J., \& Piccolo, M. C. (2020). Impact of heatwave events on latent and sensible surface heat flux and future perspectives in shallow lakes based on climate change models. Cuadernos de Investigación Geográfica, 47(2), 457-475. https://doi.org/10.18172/cig.4456

Aliaga, V. S., Ferrelli, F., Alberdi-Algarañaz, E. D., Bohn, V. Y., \& Piccolo, M. C. (2016). Distribución y variabilidad de la precipitación en la Región Pampeana, Argentina. Cuadernos de Investigación Geográfica, 42(1), 261-280. https://doi.org/10.18172/cig.2867

Aliaga, V. S. (2020). Tendencia y variabilidad climática: subregiones Pampeanas, Argentina (1960- 2010). Boletín Geográfico, 42(1), 13-32. Recuperado de http://170.210.83.53/htdoc/revele/index.php/ geografia/article/view/2700

Allende, L., Tell, G., Zagarese, H., Torremorell, A., Pérez, G., Bustingorry, J., ... \& Izaguirre, I. (2009). Phytoplankton and primary production in clear-vegetated, inorganic-turbid, and algal-turbid shallow lakes from the pampa plain (Argentina). Hydrobiologia, 624(1), 45-60. https://doi.org/10.1007/ s10750-008-9665-9

Baigún, C. R. M., \& Delfino, Y. R. L. (2003). Sobre ferrocarriles, lagunas y lluvias: características de las pesquerías comerciales de pejerrey en la cuenca del río Salado (Provincia de Buenos Aires). Biología Acuática, 20(20), 12-18. Recuperado de https://revistas.unlp.edu.ar/bacuatica/article/view/6799

Barley, E. M., Walker, I. R., Kurek, J., Cwynar, L. C., Mathewes, R. W., Gajewski, K., \& Finney, B. P. (2006). A northwest North American training set: Distribution of freshwater midges in relation to air temperature and lake depth. Journal of Paleolimnology, 36(3), 295-314. https://doi.org/10.1007/ $\underline{\text { s10933-006-0014-6 }}$

Barragan, F. G., \& Geraldi, A. M. (2018). Aplicación de teledetección para la determinación de zonas inundadas en la llanura Pampeana de Argentina. X Congreso Internacional Geomática 2018. Recuperado de http://www.informaticahabana.cu/sites/default/files/ponencias2018/GEO143.pdf 
Bauer, M., Del Genio, A. D., \& Lanzante, J. R. (2002). Observed and simulated temperature-humidity relationships: Sensitivity to sampling and analysis. Journal of Climate, 15(2), 203-215. https://doi. org/10.1175/1520-0442(2002)015<0203:OASTHR>2.0.CO;2

Bohn, V. Y. (2009). Geomorfología e hidrografía de las lagunas del sur de la provincia de Buenos Aires (Tesis doctoral). Universidad Nacional del Sur. Bahía Blanca. Recuperado de http://repositoriodigital.uns. edu.ar

Burnham, K. P., \& Anderson, D. R. (1998). Practical Use of the Information-Theoretic Approach. En Model Selection and Inference, 75-117. https://doi.org/10.1007/978-1-4757-2917-7_3

Casado, A. L., \& Campo, A. (2019). Extremos hidroclimáticos y recursos hídricos: estado de conocimiento en el suroeste bonaerense, Argentina. Cuadernos Geográficos, 58(1), 6-26. http://dx.doi.org/10.30827/ cuadgeo.v58il.6751

Coats, R., Perez-Losada, J., Schladow, G., Richards, R., \& Goldman, C. (2006). The warming of Lake Tahoe. Climatic Change, 76(1-2), 121-148. https://doi.org/10.1007/s10584-005-9006-1

Dangavs, N. (2005). Los ambientes acuáticosde la provincia de Buenos Aires. Capítulo XIII. En Relatorio del XVI Congreso Geológico Argentino, La Plata, 219-235. Recuperado de http://naturalis.fcnym.unlp. edu.ar/id/003950

Ekmekei, M., \& Tezcan, L. (2006). Assessment of vulnerability of wáter resources to climate change; ecohydrologycal implications. In A.Baba, K. Howard, \& O. Gunduz (Eds.), Proceedings of the NATO advanced research workshop on groundwater and ecosystems (pp 59-69). Springer, Dordrecht

Erler, A. R., Frey, S. K., Khader, O., d'Orgeville, M., Park, Y. J., Hwang, H. T., ... \& Sudicky, E. A. (2019). Evaluating Climate Change Impacts on Soil Moisture and Groundwater Resources Within a LakeAffected Region. Water Resources Research, 55(10), 8142-8163. https://doi.org/10.1029/2018WR023822

Fan, Y., \& van den Dool, H. (2008). A global monthly land surface air temperature analysis for 1948present. Journal of Geophysical Research, 113(D1), 1-18. https://doi.org/10.1029/2007JD008470

Fee, E. J., Hecky, R. E., Kasian, S. E. M., \& Cruikshank, D. R. (1996). Effects of lake size, water clarity, and climatic variability on mixing depths in Canadian Shield lakes. Limnology and Oceanography, 41(5), 912-920. https://doi.org/10.4319/lo.1996.41.5.0912

Geraldi, A. M. (2009). Estudio geoambiental de la cuenca lagunar Las Encadenadas del Oeste (Tesis doctoral). Universidad Nacional del Sur. Bahía Blanca. RRecuperado de http://repositoriodigital.uns.edu.ar

Geraldi, A., Piccolo, C., \& Perillo, G. (2010). Delimitación y estudio de cuencas hidrográficas con modelos hidrológicos. Investigación Geográfica, 16(30), 215-225. https://doi.org/10.4067/S0718$\underline{09342002005100014}$

Hartmann, D. L., Klein, A. M. G, Tank, M. Rusticucci, L.V. Alexander, S. Brönnimann, Y., ... \& Zhai, P.M. (2013). Observations: Atmosphere and Surface. In: Climate Change 2013: The Physical Science Basis. Contribution of Working Group I to the Fifth Assessment Report of the Intergovernmental Panel on Climate Change. 159-254. https://doi.org/10.1017/CBO9781107415324.008

Intergovernmental Panel on Climate Change. (2000). Ipcc Special Report. Emissions Scenarios A Special Report of IPCC Working Group III.

Intergovernmental Panel on Climate Change. (2012). Managing the Risks of Extreme Events and Disasters to Advance Climate Change Adaptation. A Special Report of Working Groups I and II of the Intergovernmental Panel on Climate Change. Cambridge, UK and New York, NY, USA.

Intergovernmental Panel on Climate Change. (2014). Climate Change 2014: Impacts, Adaptation, and Vulnerability. Part A: Global and Sectoral Aspects. Cambridge, United Kingdom and New York, NY, USA.: Cambridge University Press.

Jeppesen, E., Kronvang, B., Meerhoff, M., Søndergaard, M., Hansen, K. M., Andersen, H. E., ... \& Olesen, J. E. (2009). Climate Change Effects on Runoff, Catchment Phosphorus Loading and Lake Ecological State, and Potential Adaptations. Journal of Environment Quality, 38(5), 1930. https://doi.org/10.2134/ jeq2008.0113

Jeppesen, E., Søndergaard, M., \& Liu, Z. (2017). Lake restoration and management in a climate change perspective: An introduction. Water (Switzerland), 9(2), 122. https://doi.org/10.3390/w9020122 
Jones, R. N., McMahon, T. A., \& Bowler, J. M. (2001). Modelling historical lake levels and recent climate change at three closed lakes, Western Victoria, Australia (c.1840-1990). Journal of Hydrology, 246(1-4), 159-180. https://doi.org/10.1016/S0022-1694(01)00369-9

Kaufman, Y. J., Wald, A.E, Remer, L. A. Gao, B.-C. Li, R.-R., \& Flynn, L. (1997). The MODIS 2.1- ChannelCorrelation with Visible Reflectance for Use in Remote Sensing of Aerosol. IEEE Transactions on Geoscience and Remote Sensing, 35(5), 1286-1298. https://doi.org/10.1109/36.628795

Koninklijk Nederlands Meteorologisch Instituut. (2008). Royal Nethherland Meteorological Institute. Recuperado de https://climeexp.knmi.nl/start.cgi?someone@somewhere

Kundzewicz, Z., Mata, L., Arnell, N., Doll, P., \& Kabat, P. (2007). Freshwater resources and their management. Recuperado de http://centaur.reading.ac.uk/1017

Leemans, R., \& Eickhout, B. (2004). Another reason for concern: Regional and global impacts on ecosystems for different levels of climate change. Global Environmental Change, 14(3), 219-228. https://doi.org/10.1016/j.gloenvcha.2004.04.009

Li, B., Zhang, J., Yu, Z., Liang, Z., Chen, L., \& Acharya, K. (2017). Climate change driven water budget dynamics of a Tibetan inland lake. Global and Planetary Change, (150), 70-80. https://doi.org/10.1016/j. gloplacha.2017.02.003

Londoño, O. M. Q., Martinez, D. E., \& Massone, H. E. (2012). Comparative assessment of recharge estimation methods in plain environments. The inter-mountainous plain (Argentina) as a case study. Dyna, 79(171), 239-247. Recuperado de http://www.scielo.org.co/scielo.php?script=sci arttext\&pid=S0012-73532012000100030

Magnuson, J. J., Robertson, D. M., Benson, B. J., Wynne, R. H., Livingstone, D. M., Arai, T., ... \& Vuglinski, V. S. (2000). Historical trends in lake and river ice cover in the Northern Hemisphere. Science, 289(5485), 1743-1746. https://doi.org/10.1126/science.289.5485.1743

Magrin, G. O., Gay Garcia, C., Cruz Choque, D., Gimenez-Sal, J. C., Moreno, A. R., Nagy, G. J., ... \& Villamizar, A. (2007). Climate Change and Climate Variability in the Latin American Region. AGUSM, 2007, U33B-02. IPCC 581-615. Recuperado de https://ui.adsabs.harvard.edu/abs/2007AGUSM. U33B..02M/abstract

Meehl, G., Stocker, T., Collins, W., \& Friedlingstein, P. (2007). Global climate projections. IPCC. Recuperado de https://publications.csiro.au/rpr/pub?list=BRO\&pid=procite:1452cb7a-9f93-44ea9ac4-fd9f6fd80a07

Milly, P. C. D., Dunne, K. A., \& Vecchia, A. V. (2005). Global pattern of trends in streamflow and water availability in a changing climate. Nature, 438(7066), 347-350. https://doi.org/10.1038/nature04312

Monti, A., \& Escofet, A. (2008). Ocupación urbana de espacios litorales: Gestión del riesgo e iniciativas de manejo en una comunidad patagónica automotivada (Playa Magagna, Chubut, Argentina). Investigaciones Geograficas (Mx), 67, 113-129. Recuperado de https://www.redalyc.org/ pdf/569/56911125008.pdf

Nicholson, S.E. (1999). Historical and modern fluctuations of Lakes Tanganyika and Rukwa and their relationship to rainfall variability. Climate Change, 41, 53-71.

Palmer, M. A., Reidy Liermann, C. A., Nilsson, C., Flörke, M., Alcamo, J., Lake, P. S., \& Bond, N. (2008). Climate change and the world's river basins: Anticipating management options. Frontiers in Ecology and the Environment, 6(2), 81-89. https://doi.org/10.1890/060148

Peeters, F., Livingstone, D. M., Goudsmit, G.-H., Kipfer, R., \& Forster, R. (2002). Modeling 50 years of historical temperature profiles in a large central European lake. Limnol. Oceanogr, 47(1), $186-197$. https://doi.org/10.4319/lo.2002.47.1.0186

Plumb, J. M., \& Blanchfield, P. J. (2009). Performance of temperature and dissolved oxygen criteria to predict habitat use by lake trout (Salvelinus namaycush)This paper is part of the series "Forty Years of Aquatic Research at the Experimental Lakes Area". Canadian Journal of Fisheries and Aquatic Sciences, 66(11), 2011-2023. https://doi.org/10.1139/F09-129

Quirós, R. (2000). La eutrofización de las aguas continentales de Argentina. Ciencia y Tecnología para el Desarrollo (CYTED), 43-47. Recuperado de https://www.agro.uba.ar/users/quiros/Eutrofizacion/ EutroArgentina.pdf 
Rosenzweig, C., Casassa, G., Karoly, D.J., Imeson, A., Liu, C., Menzel, A., ... \& Seguin B, T. P. (2007). Assessment of observed changes and responses in natural and managed systems. Recuperado de https://www. zora.uzh.ch/id/eprint/33180/1/Rosenzweig_Assessment_Observed_Changes_Responses_2007.pdf

Salvia, M. M., Karszenbaum, H., Kandus, P., \& Grings, F. M. (2009). Datos satelitales ópticos y de radar para el mapeo de ambientes en macrosistemas de humedal. Revista de Teledetección, 31, 35-51. Recuperado de http://www.aet.org.es/congresos/xii/arg26.pdf

Schröter, D., Cramer, W., Leemans, R., Prentice, I. C., Araújo, M. B., Arnell, N. W., ... \& Zierl, B. (2005). Ecosystem service supply and vulnerability to global change in Europe. Science, 310(5752), 1333-1337. https://doi.org/10.1126/science.1115233

Shi, Y., Shen, Y., Kang, E., Li, D., Ding, Y., Zhang, G., \& Hu, R. (2007). Recent and future climate change in northwest China. Climatic Change, 80(3-4), 379-393. https://doi.org/10.1007/s10584-006-9121-7

Sun, Y.-J., Lu, S.-Q., Lin, W.-Q., Wang, D.-Z., Fan, J.-Y., \& Li, Z. (2016). In-situ study on nutrient release fluxes from shallow lake sediments under wind-driven waves. Journal of Hydrodynamics, 28(2), 247-254. https://doi.org/10.1016/S1001-6058(16)60626-1

Tezcan, L., Ekmekci, M., Atilla, O., Gurkan, D., Yalcinkaya, O., Namkhai, O., ... \& and Ahmet Irvem. (2019). Assessment of Climate Change Impacts on Water Resources in the Somme River Basin (France). Water Resources Management, 33(6), 2073-2092. https://doi.org/10.1007/s11269-019-02230-x

Torremorel, A., Bustigorry, J. Escaray, R., \& Zagarese, H. (2007). Seasonal dynamics of a large, shallow lake, laguna Chascomús: The role of light limitation and other physical variables. Limnológica, 37, 100-108. https://doi.org/10.1016/j.limno.2006.09.002

Trenberth K. E., Jones P .D., Ambenje P., Bojariu R., Easterling D., Klein Tank A., ... \& Rusticucci M., S. (2007). Observations: Surface and atmospheric climate change. Recuperado de https://cig.uw.edu/ publications/observations-surface-and-atmospheric-climate-change/

Verburg, P., Hecky, R. E., \& Kling, H. (2003). Ecological consequences of a century of warming in Lake Tanganyika. Science, 301(5632), 505-507. https://doi.org/10.1126/science.1084846

Vincent, W. F. (2009). Effects of Climate Change on Lakes. En Encyclopedia of Inland Waters (pp. 55-60). Elsevier Inc. https://doi.org/10.1016/B978-012370626-3.00233-7

Yang, X., \& Lu, X. (2014). Drastic change in China's lakes and reservoirs over the past decades. Scientific Reports, 4(41001362). https://doi.org/10.1038/srep06041

Zunini, J. Ferrelli, F., \& Piccolo, M. C. (2018). Cambios morfométricos en una laguna pampeana (Argentina) como consecuencia de la variabilidad Pluviométrica (1960-2015) y sus posibles efectos sobre la Comunidad ictica. Geociencias, 37(4), 835-847. https://doi.org/10.5016/geociencias. v37i4.11980 